\title{
Post-crisis LGBTQ film- and video-making in Spain: Two case studies
}

DOI:

10.1080/14636204.2017.1336323

\section{Document Version}

Accepted author manuscript

Link to publication record in Manchester Research Explorer

\section{Citation for published version (APA):}

Perriam, C. (2017). Post-crisis LGBTQ film- and video-making in Spain: Two case studies. Journal of Spanish Cultural Studies, 291-304. https://doi.org/10.1080/14636204.2017.1336323

\section{Published in:}

Journal of Spanish Cultural Studies

\section{Citing this paper}

Please note that where the full-text provided on Manchester Research Explorer is the Author Accepted Manuscript or Proof version this may differ from the final Published version. If citing, it is advised that you check and use the publisher's definitive version.

\section{General rights}

Copyright and moral rights for the publications made accessible in the Research Explorer are retained by the authors and/or other copyright owners and it is a condition of accessing publications that users recognise and abide by the legal requirements associated with these rights.

\section{Takedown policy}

If you believe that this document breaches copyright please refer to the University of Manchester's Takedown Procedures [http://man.ac.uk/04Y6Bo] or contact uml.scholarlycommunications@manchester.ac.uk providing relevant details, so we can investigate your claim.

\section{OPEN ACCESS}




\title{
Post-crisis LGBTQ film- and video-making in Spain: Two case studies
}

Chris Perriam

School of Arts, Cultures and Languages, University of Manchester, Manchester, UK

\begin{abstract}
This essay is concerned with the ways in which the social, political and economic aftermath of the 2007-2008 global financial crisis has shaped small-scale, independent film- and video-making in Spain, specifically by LGBTQ artists. Exploring two autonomous author-producer-agencies Emociones Produce/WeShoot Agencia Visual/Juanma Carrillo and Volando Vengo-Moviethinking/ Rut Suso - it considers their strategies in relation to processes of austerity and attrition, circa 2012 to 2016. The main concern is with alterations in forms of expression in a directly visual sense but also in forms of professional survival; detailed analysis of these aspects is undertaken in order to nuance understandings of the cultural effects of crisis and post-crisis in Spain. The essay covers both niche queer video and the imagery of social and commercial entrepreneurialism. Where EmocionesProduce/Carrillo's work is marked by the image of the vulnerable body and a mood of disruption, the varied image work of Volando Vengo-Moviethinking/Suso places commercial and social commitments in a tensive relationship with artistic demands in a bricolage of socialentrepreneurial, creative and pragmatic effects. Attending to crossovers in both case studies between art making, filmmaking and commissioned publicity helps add detail to the map of the processes of crisis and post-crisis in Spain in recent years.
\end{abstract}

\section{KEYWORDS}

LGBTQ audiovisuality, entrepreneurialism, crisis, Spain, Juanma Carrillo, Rut Suso 


\section{Introduction}

This essay is concerned with the ways in which the social, political and economic aftermath of the 2007-2008 global financial crisis, and its particular and accentuated effects in Spain, have shaped small-scale, independent film- and video-making. The particular focus is on two case studies with their origins in LGBTQ filmmaking: EmocionesProduce, with artist-musician-director Juanma Carrillo at its creative core, and Volando Vengo-Moviethinking, with Rut Suso and María Pavón at its. The essay will trace both the diversifying moves that these artists have had to make and the resultant changes in the ways their images are shaped. It will focus on a sample of works made between 2012 and 2016 and on how the ongoing processes of austerity and attrition, or post-crisis, have shaped them and the professional decision making underlying them. This, it is hoped, will help nuance understandings of the effects of crisis and post-crisis in Spain in recent years on a creative sector that has strong ties to queer and feminist concerns but which also engages with the imagery, and some of the assumptions, of social and commercial entrepreneurialism.

As is well enough known, in the earlier phase of the period discussed here, Spanish government funding and institutional support for culture fell away sharply (Álvarez Monzoncillo and López Villanueva, 66; Bustamente Ramírez, 12). For cinema, it was a period of "a shrinking and increasingly polarised film industry [with] resources (especially from television) cluster[ed] around fewer, bigger titles" (Kourelou et al. 143; confirmed by statistics presented by Badillo). The Instituto de la Cinematografía y las Artes Audiovisuales (ICAA) was forced to make especially acute cuts to its support for Spanish cinema in 2012 and 2013 (Bustamente Ramírez 12; Zurro). These material cuts were combined with a lack of transparency and of fairness in applying decisions made by funding bodies (Bustamente Ramírez 14), and neither political promises of new systems of financing nor the encouragement of mecenazgo had substantial counter-effects (Bustamente Ramírez 39). In 2014, for instance, the LesGaiCineMad film festival's funding from the Comunidad 
de Madrid cultural department was withdrawn in its totality, and the festival resorted to a crowdfunding campaign. As the crowdfunding page linked from the festival's Facebook page had it:

El festival que tú conoces (o del que has oído hablar) quizá sí esté a punto de desaparecer. A pesar de contar con más de 14.000 espectadores cada año, los bolsillos de los mecenas habituales de la cultura madrileña están cada vez más escasos. (LesGaiCineMad)

This language of scarcity, disappearance and - in the title of the call for funding - danger is not only part of the rhetoric of any appeal of this sort but also reveals the discursive framework for much of the visual production with which this essay is concerned. The language responds, also, to a far wider context of austerity, crisis, disrupted lives, labour and precarity, themselves globally informed (and caused) by neoliberalism - a context briefly reviewed below as a way of setting out coordinates for the analysis of creative practice that follows. Cameron has addressed the crucial question of the ethical style of this particular cultural moment and its responses, highlighting the ways in which the 15-M movement - and critical talk around it - attempts to "produce new imaginaries and articulate alternative subjectivities in a time of crisis" (4). Allbritton (drawing on the work of Laurent Berlant, Judith Butler, Ann Cvetkovich and Lee Edelman, among others) has summarized how "the representations of Crisis that have increasingly filled Spanish theaters, bookstands and computer screens loop together political and physical vulnerability tightly" (102); the circumstances of production, the form and the themes of Spanish cinema are all linked strongly to crisis and precarity $(105-107 ; 113 n 5-6)$. From another angle, in considering the Cineteca de Madrid's curation in 2013 of a season of politically-themed shorts - “Revolución española?” Marsh has pointed out ways in which such filmmaking is semi-allegorically disrupted or split by "una temporalidad descolocada" and by generic uncertainty. 
One key feature that will be seen to mark the work examined here is, indeed, disruption. It is the disruption associated with precarity taken to represent a broad set of effects of post-Fordist labour practices, policies and gendered power relations (Bologna and Fumagalli; Colectivo Precarias a la Deriva). In Carrillo there is also an aesthetic of precarity built around representations of hard emotional labour and feelings of abandonment. In the work of both Carrillo and Volando Vengo there are, on the other hand, signs of precarity as regards its ability to supply "the precondition for new forms of creative organization that seek to accept and exploit the flexibility inherent in networked modes of sociality and production" (Neilson and Rossiter). Their work is shaped by the ambivalent disruption (destructive yet reconstructive) associated with crisis, postcrisis and austerity as experienced in Spain and the European South (Guillén, González-Begega and Balbona) and as part of the global set of effects proper to the neoliberal dispensation whose history has been much discussed in the social sciences and in cultural criticism (see Harvey; Rose; Duggan).

Castells, Caraça and Cardoso, whose edited volume of essays, Aftermath: The Cultures of the Economic Crisis, leaves off more or less at the date when the case studies selected here begin (around 2012), provide in their introduction an important analytical overview of the crisis of global capitalism, critical responses to it and its possible aftermaths. Summarising earlier work, they propose that as socio-economic restructuring unfolds the crisis - "not merely economic" but "structural and multidimensional” (“An Introduction" 1) - can be assumed to give rise to "protocultural forms" in the "spontaneous adaptation of peoples' lives to [its] constraints and opportunities" (4). Such adaptation is a second key feature in the work to be studied here. Adaptation in practice, in these cases, can be seen as a response to precarity's ambivalent disruption, alluded to above. It works through the tensions between politically imposed austerity the long process of dismantling the state - and "new modes of expectation" that are creative, collective and resistant (Bramall 2, 9). These modes, which exist at the social level, are reflected in 
our case studies at the representational level as similarly creative, resistant and - inasmuch as they adapt working practices previously designed for consumption by and awareness-raising in the LGBTQ community - collective. The works are also attuned to the mood of austerity, as Coleman has suggested in a different context, manifesting itself as an "orchestration of affects, feelings and emotions" (90). As such, they indirectly "work on the future" (Bramall 9) in ways that overcome the scarcities, the disappearances of cultural goods and the dangers alluded to paradigmatically in LesGaiCineMad's crowdfunding call, above. Precarity's disruption goes hand in hand with adaptation in terms of practice.

Additionally, as part of their predictive analysis of crisis, Castells, Caraça and Cardoso see the emergence of a four-layer economy of which the fourth layer will be "an alternative economy sector (not necessarily excluding for-profit production) based on a different set of values about the meaning of life" (12). Just such a combination of "alternative economy" and "different values" shapes the immaterial labour of Carrillo, Suso and Pavón. Gill and Pratt review the work done on precarious creative labour and summarize its key features within such an "alternative" and "different" context of monetary and social values: they highlight intermittence, "passionate attachment ... to the identity of creative labourer" and "an attitudinal mindset that is a blend of bohemianism and entrepreneurialism" (14). Alternative entrepreneurism drawing on principles of social innovation, with its inevitably political inflections, is yet another key aspect of the work to be discussed here, which displays the features identified by Gill and Pratt. Volando Vengo in particular deploys some of the same tactics as social entrepreneurs, who usually work to "tackle unmet socio-economic needs using innovative approaches" (Shaw and Carter 418). Innovation in this sense is closely tied to the recombination of resources geared toward social change (Mair and Marti), and Di Domenico, Haugh and Tracey identify a Levi-Straussian bricolage effect, a "carry[ing] over or recombination of resources" (690) that characterizes the actions of "most entrepreneurs", who "operate under conditions of resource scarcity" (683). Carrillo and Volando Vengo can be seen to be exploiting the archive of their own queer and feminist artistic origins, recombining key cultural resources and artistic skills sets, working towards a new sensibility and a 
new imaginary (in Carrillo) and towards social change explicitly (in Volando Vengo's work under the hashtag "moviethinking", as will be seen). That is to say, the two case studies in this essay reveal an adaptive creativity across a range of practices from the pragmatically responsive, and even the complicit, to the artistically inspired and creatively innovative. Some of the works to be studied are the result of straightforward commissions, others respond to the need to develop tactics independent from conventional means of production, promotion and distribution in a context of scarcity (Ballesteros). ${ }^{i}$ They will now be considered in light of disruption as a concomitant of precarity and as an artistic marker, in light of adaptation in practice as a response to new socioeconomic and cultural contexts and in light of the ways in which alternative entrepreneurship negotiates some of the basic ambivalences and tensions in situations of crisis and post-crisis.

\section{Juanma Carrillo, EmocionesProduce, WeShoot Agencia Visual: Disruption and adaptation} in practice

Juanma Carrillo is a polymathic, photo and video artist and filmmaker who is well known on the LGBT film festival circuit (Perriam 107-111). He has especially close connections with the Mostra FIRE!! film festival in Barcelona, and with the LesGaiCineMad festival (mentioned above), which included a section in homage to him at the 2015 festival. With Joako Ezpeleta, codirector of Mostra FIRE!!, he set up WeShoot, ${ }^{\mathrm{ii}}$ a video production company and audiovisual agency in late 2013. Since the festival circuit is one of the three key networks into which Carrillo feeds his work, it is worth briefly reviewing the effects of the crisis and its aftermath on this niche sector. In conversation in Madrid, Ezpeleta underlined how particularly hard-hit the Spanish LGBT festivals had been with their high degree of dependence on funding from municipalities and autonomous communities. Financial constraint had led generally to better quality in the films coming to festivals, in Ezpeleta's view, and to a notable rise in the areas of documentary and trans-themed shorts. Nevertheless, severe cuts in funding and reductions in support had led to the disappearance of at least four smaller LGBT film festivals in Spain (out of twelve in 2008) and ongoing uncertainty for the larger ones. Mostra FIRE!!'s organizational infrastructure and running depend 
precariously on its volunteer force (members of the activist and community group Casal Lambda), to whom, in a process typical of precarity, the burden of labour is transferred; it has also depended in recent years on free use of the facilities of the Institut Français, Barcelona (Perriam and Waldron 52-53). The Madrid festival is similarly dependent (in its case, on the infrastructure and volunteers of the Fundación Triángulo) and Ezpeleta expanded on the sense of precariousness that emerged from the Madrid experience by referring not only to the evaporation of sponsorship in the form of direct funding but also to an ever-growing wariness among public bodies and the commercial sector towards support for LGBT events (which he attributed, credibly enough, to a tacit form of institutionalized homophobia). As Ezpeleta emphasized, a recognizable image, "una personalidad visual", is crucial to enterprises such as these festivals, and without either the aura of commercial sponsorship or the basic funding that accompanies it, the quality and the effective dissemination of such an image is under strain.

The recognizable image of Mostra FIRE!! has, nevertheless, been strongly enhanced since 2011 by posters, teasers and spots by Carrillo and by his close involvement behind the scenes and at events. The official spot for 2014, "Born Heroes" (with Elena Anaya and produced by WeShoot), is an elegantly indirect homage to David Bowie. 2011's "I'm On Fire" intriguingly mismatches the uber-gay "I Feel Love" (by Donna Summer - much covered by gay male artists) with knowingly glam lesbian narcissism. Three fragmentary but lavishly finished pieces for 2012 not only draw their audiences in through strong generic familiarity (in this case, with the style of the making-of) but also wrong-foot them with more odd mismatches and a sense of incompletion. "Furry Boys" is a playful sideways glance at the furry movement (but without saying why) and is about the difficulties of making low-budget gay romance, featuring young actors in cheap, bleak, but evocative settings (such as an abandoned swimming pool in a non-specific leisure complex). "La lettera" references both schoolgirl-for-mistress-crush stories and, very obliquely and laconically, Italian classic cinema. "Estafa", most notably, begins with passionate on-the-floor sex between two 
sexily scruffy men (two well-known screen actors, Ramón Moreno and Borja Luna) and morphs into a dark comic dialogue in which one of the lovers breathlessly manages to announce that he has lost his job but did not know how to tell the other. The actors themselves get put off their stride, and the camera crew, suddenly revealing the mise en abîme, appear behind them exhorting them to leave the crisis out of things and try to put the fire back in the scene (Casal Lambda and Juanma Carrillo). ${ }^{\text {iii }}$ The English presentation of the piece on WeShoot's Vimeo page still playfully suggests that "good sex is the only way to overcome the financial crisis" (WeShoot Agency), and, in a more serious mode, this intense cameo dramatizes and embodies, for the Spain of its time, the mood of austerity (to reuse Coleman's term: 90, 98-99).

The set used for "Estafa" is recognizably the same as for the internationally screened short Andamio/Scaffolding (2012) (Dishonoured Bodies) which makes similar use of a modest urban interior (in all probability the director's Madrid apartment and digital studio at the time, half a kilometre from the Plaza de España). It does so in order to encapsulate a different form of bonding between two neighbours who, while work is done to the facade of their building, find that the scaffolding that has been put up creates a liminal space between their balconies, which will host emotional uncertainty and erotic ambiguity between men. The scaffolding, a mainly empty street scene and the quietly sporadic construction outside all gather resonance as the men continue not to communicate. As movements of air caught on the soundtrack suggest the sounds of the open countryside, or the distant seashore, to the attentive audience, several structures of association are slowly pieced together. The drama of tentative flirtation and studied avoidance and the temporary nature of the scaffolding evoke wider feelings of precariousness or thoughts about missed chances and the decay of the moment of desire. Cinephiles in the audience, too, may be drawn towards the sort of meditations on temporality that are so courted, in a different city, by the slow-cinema piece En construcción (directed by José Luis Guerín). There, construction work in Barcelona’s Raval neighbourhood and the work of disruption in the name of capitalist planning and regeneration are 
visually intertwined. In Carrillo's piece, more tacitly and with a much lighter touch, the desolation of human reticence and of the repairing and retouching of the urban fabric are also joined. With Spain's particular crisis so closely associated with the collapse of the property boom, the gentle failure of two neighbours to connect while their street is patched up in a half-hearted prelude to gentrification is evidently a construction that pieces together the global-social and the everydaypersonal.

Similar connections are made in Carrillo's major, but stalled, project, Islandia. Continually deferred in favour of the sort of shorter pieces that have just been discussed, the project has a fragmentary but increasingly suggestive presence on social media, on Carrillo's web pages and, up to 2016 at least, in festival workshops and other appearances. The presentational package for the project, with the old-style literary label "Hielo quema”, answers the question "¿Por qué Islandia?" by citing the power of attraction of landscape, artistic and musical heritage and the notion of "un país inquietante" along with the fact that:

Islandia ha sufrido en estos últimos años una crisis económica brutal, muy similar a la que ahora sufre España, pero su gestión de la misma ha sido completamente diferente. El papel activo de la sociedad civil ha sido determinante para sacar a la luz los verdaderos motivos de la crisis, y poner el foco en los agentes activos que la han originado. (Carrillo, Hielo quema)

In the available preview material, the bleak emotional distances that open up between the three protagonists - Blanca, her brother Miguel and Adamsonn his lover (and, eventually, briefly, Blanca's lover) - are matched in the perspectives and tonalities of the film's proposed treatment of the landscape and its climate, of snow and volcanic geology. In addition to creating a pervading sense of foreboding intensified by passion in the dramatic mood of the piece, the film also registers 
the economic climate. Icelandic landscapes are also connected to crisis in Inside Job (directed by Charles Ferguson, 2010), which Kinkle and Toscano see as an example of "a contemporary trend to represent global capitalism and its effects through a kind of slick, naturalistic sublime" (50), and there is an element of this quality in some of the material presented for Carrillo's film. However, the stills on the project web page suggest a less slick emphasis on post-Romantic subjectivity, and they give psychological realism a queer twist. An old-fashioned interest in a tragic, triangular relationship, and - through images of rocks, ice and storms - in transcendence, awe and sublimity is tempered by an insistence on bodies in the throes of jealousy and desire as brute matter in conflict.

The mood is austere, communication disrupted.

In the Hielo quema package, poetic texts in quasi-diary format are interspersed with three sets of photographs of the Icelandic landscape, of Reykjavik and of isolated human and animal subjects. The purity of the old conceit of the Icy Fire is both jeopardized and enhanced here. The photographs refer to emotional pain, a purifying quest (a climb towards the glacial, indifferent lover) and the dark, calming, annihilating beauty of desolation (and of the never mentioned and never pictured lover). One especially haunting image in the first set of photos (labelled "Pictures") depicts a group of horses in the half light, like fieldworkers bent over an unforgiving land, with power cables constructing a geometry of emotional pain and with a pylon in the mid-field set against icy hills. Brute subsistence is triumphant over modernity's attempts to energize human lives (or national economies). Also, however, there are images of urban modernity (the power cable motif links wilderness and city) and material solitude (for example, a classically shot empty bus shelter in "Pictures II"). In the Videos section, "La noche" excavates in slow-cinema style the dramatic and affective possibilities of dark streets, light reflected on water, passing cars and passing people (and, in the voice-over spoken by the director, a grand post-Romantic urge to look into the abyss). In "El banco" a lone bench faces a blue-grey vista over a bay with cloud- and snow-capped hills rising in the background; behind the bench is a little-frequented pedestrian walkway and desultory passing 
traffic on the road in the foreground (picking up on a car-based conceit in another classically shot image, that of an empty car park as the modern void, in "Pictures III").

The Islandia project has been to all intents and purposes made ephemeral by the circumstances of crisis and post-crisis, with no big backers and no prospect of a break-through as of the end of 2016. In conversation in Madrid, Carrillo spoke, unsurprisingly, of how each new commission implied a radical adaptation of the programme of work on other more purely artistic projects (Islandia, as above, but also a new short fiction film). He also spoke of "la búsqueda de una determinada sensibilidad, un afán de estilo" informing his work - under his own name and under the label EmocionesProduce. By extension, the work of WeShoot crosses over between the markedly auteurist (what Carrillo's website calls "Personal Works") and the commercially creative. A trio of music videos for "La Bien Querida" (Ana Fernández, lead singer and founder) released in 2014-2015 is at once a response to business needs, economic necessity and the urge to consolidate a distinct style. For “Poderes extraños: Pre-Meditación” (2014), “Ojalá estuvieras muerto:

Nocturnidad" (2015) and "Muero de amor: Alevosía" (2015), Carrillo - given artistic free rein, according to Fernández (La Bien Querida) - responds to the way in which a "new auteurism" feeds into and off of the music video tradition (Ashby; Vernalis 234-61). The songs were somewhat archly released on the sixth of October 2014, January 2015 and March 2015, as "un disco marcado por tres seises" (La Bien Querida). The publicity speaks of the "misterio muy particular" that is contained in Carrillo's material (Elefant Records). The visuals play up to the expectations of weirdness that are thus created, and they have a strange and sinister beauty that is at times in tune, but at other times productively at odds, with the lyrics of the three songs. All three videos draw in a fragmentary manner on film dramas of the paranormal, with an implied alien abduction-cumpossession narreme, complete with a car on a lonely road (in "Ojalá estuvieras muerto: Nocturnidad"), and with child protagonists (including spooky twins) staring and pointing, at different moments, at an invisible point in the distance suggestive of impending mayhem, invasion 
or visitation. One young boy, whose presence is a kind of narrative guide, is strongly reminiscent of Victor in the French/international television drama Les Revenants (Canal+ 2012-2015). Adults sing tearfully and resentfully of love while standing looking out across bleak moorlands; in other landscapes, adults lie flat, dead on the ground of what is made to seem a generically northernlatitude wooded environment (in fact, in Carrillo's native La Rioja). After aerial shots over snowy pine forests in the title sequence of the first of the trilogy, there follows a sustained black-and-white pastiche of, perhaps, Eisenstein's Oktyabr (October: Ten Days That Shook the World) (1928) and something very like Tarkovski's brand of paranormal metaphorizing. Again alluding to Tarkovski (among others), the video shows a young girl at a table causes a glass to shift, and children generally deploy psychokinetic powers. This all constructs a particular feel to the videos across the trilogy (though the last is more upbeat and redemptive), displaying not only inspiration in "el cine nórdico y ruso" or, more definitely, the "claro homenaje al cine ruso" that Carrillo acknowledges (Carrillo, "Juanma Carrillo”), but also an oblique line back to the Spanish ¿Quién puede matar a un niño? (directed by Narciso Ibáñez Serrador, 1976), as again Carrillo recognizes (Carrillo, “Juanma Carrillo"). Carrillo's work with La Bien Querida is very much in line with the form of the classic music video in that it confers a strangeness on everyday objects (Vernalis 206), has an uncanniness that is created by use of colour (and filters) (206) and makes use of the "intertextuality and remediation [that is] frequent in the form" as well as "affective overload amplified by ... music" (227-28). These contribute to the new auteurist markings here and give a particular aesthetic and metaphorical configuration to the dramas of uncertainty that these three pieces, and the other works discussed, return to - sometimes with deliberate fragmentary intent, sometimes with the accidental just-in-timeness of agency work and alternative entrepreneurialism (discussed in the next section).

In parallel to this work, Carrillo was engaged by the Madrid-based touring theatre company La Joven Compañía to design publicity stills, posters and promotional spots for Fuente Ovejuna 
(April 2015, and touring spring 2016) and the Proyecto Homero (Ilíada and Odisea, played back to back, April 2016). They have the sensual intensity of his earlier film and art-photographic work, especially in their treatment of the actors' bodies, (Fuente Ovejuna; Proyecto Homero; Home page). The work for the Romeo and Juliet restaging Hey Boy Hey Girl (February 2016) draws on some of the dynamics of the dance-based video-art piece Une sensation de vide for the Barcelona LOOP festival (2012) (Carrillo, Une sensation de vide; Perriam 110-11) as well as on the moments of intense heterosexual eroticism of Perfect Day (2010), or, indeed, the Islandia project. The video's particular reworking of the Montagues' and Capulets' confrontation is set in a commercially shiny, self-consciously modern late-hours bar, and the whole work manifests chronological and generic crossovers (1300s, 1500s, 20th-century gangster era, present-day Spain; dance film, fight film, romantic drama, nightclub story) (Carrillo, Hey Boy Hey Girl). Again, edginess and violent beauty respond obliquely to the circumstances in which they are formed. Precarity begets intertextual disruption and a mood of austerity; remediation underpins a far-reaching process of adaptation in practice.

\section{Volando Vengo/Moviethinking: Adaption in practice and alternative entrepreneurialism}

For Carrillo, crisis seems to have supplied a core feeling - a sign of auteurship in adversity - as well as to have provided a sporadic thematic line to his work, since what he calls his "personal" work peaked in 2011-2012 (with Fuckbuddies and Andamio). The second case study, of the lesbianidentified enterprise Volando Vengo Producciones Creativas (with Rut Suso as creative director in partnership with María Pavón), shows a move since the mid-2000s from a fairly conventional mix of creative and activist work towards a mixed mode of cultural production. Since 2012, Volando Vengo has used the concept of Moviethinking (and the hashtag \#moviethinking), along with the 140-character self-description "estrategia audiovisual utilizada como conductora de narrativa transmedia storytelling, en la que el usuario crea contenidos" (Suso, “Conferencia moviethinking”). That is to say, Moviethinking is a training in the forms of content marketing, visual thinking, creativity and corporate social responsibility (CSR) that have been much studied and taught in 
Spain, as elsewhere, over the past decade (see Costa Sánchez and Piñeiro Ortiz; Crane and Glozer; Rodríguez Ferrándiz; Scolari Jiménez and Guerrero). In this new phase for Volando Vengo, creativity has adapted to the demands of commissions and the expectations of social commitment. Here the authorial signature - though calqued on past, individual creativity - is economic circumstance itself, and creative tensions arise between a markedly feminist commitment to social innovation and the neoliberal urge for apparently productive renewal. Such tensions, De Bruin Shaw and Chalmers argue (392-96), are typical of social entrepreneurship which benefits from neoliberally inspired government backing (allowing the burden of social needs to shift away from the state) and which also, however, registers "disenchantment with the existing form of capitalism” (396).

To recapitulate, between 2005 and 2007 Volando Vengo had produced four short films, including the festival and online successes Ester (2005) and Pasión por el fútbol (2007), both lesbian-alternative in outlook (Perriam 97-98, 103-106). Further complete fiction-based projects have not since emerged, although on Suso's Tumblr page there are several visual and textual sketches. Other non-fiction projects with a clear interest in sexual and gender politics have also been set aside, including the project Confessional Room (which was to have been a series of videoconfessional-booth interventions from women around the world talking about their sexuality). Instead, attention has turned to applied creative work done for other artists, commercial organizations, government departments and NGOs - teasers, trailers and music videos, spots, training videos, campaign reports and content design presentations. This adaptive response to demand bridges the territories of artistic originality, change making, programmed social innovation and organizational communication remits. It uses a particular aesthetic arrangement that not only recombines "resources" (as in the model proposed by Di Domenico Haugh and Tracey 690) but specifically combines images from previous moments in Volando Vengo's and Suso's creative 
careers with images from the various client organizations. This is an art of both making do and making change that engages with, but is not itself, business as such.

Volando Vengo presents "moviethinking transmedia" as "una actitud vital y metodología de trabajo revolucionario para marcas, organizaciones y personas" (Volando Vengo, About page). The relationship posited here among brands, organizations and people, and the stress on the innovative (or revolutionary) are symptomatic of the Spanish crisis and post-crisis. Volando Vengo's work highlights the closeness of certain forms of fiction making with brand storytelling, and it points up the similarities between the need to produce work and the more transcendent urge for creativity. It points up the overlaps between clients and audiences, both of which might be changed through the effective representation of a particular "actitud vital". The initial shape and aims of Moviethinking are outlined in a video-recorded talk (Suso, "Conferencia moviethinking”) given by Suso on 12 December 2012 at the Matadero Madrid contemporary art and design centre as part of the series "Love Mondays" supported by the self-styled collective Lo Creas o No (a group of design-based cultural-industry entrepreneurs and producers of the crowdfunded handbook Manual para emprendedores que aman los lunes). The prefatory montage, packaged on Vimeo, links images taken from earlier creative film and video work by Volando Vengo (both theatrically released and not) with more clearly product-related visuals. This bricolage uses close-ups of bodies engaged in (mostly) same-sex kisses, edited in with images of the speaker's mouth turning towards the microphone at the event, while the soundtrack mixes Julie London's 1970 version of the classic "In Other Words" with the introductory words of the talk (Suso, "Conferencia moviethinking"). Key practical questions are combined with radical juxtapositions of ideas, such as the suggestion that the post-porno movement and brand consultant Cindy Gallop’s “Make Love Not Porn” campaign actions (from 2009, ongoing) have made an equally important difference to practices of intimacy through the power of their images. Such far-flung juxtapositions are, of course, the just-in-time stuff of a semi-improvised public talk. Yet Volando Vengo's recent work is often enlivened by such 
strange hybridizations of the potentially radical and anti-capitalist with the inescapably conservative and neoliberal (as epitomized in the figure of Gallop, the pragmatist feminist CEO who sets out to change the sexual behaviour of younger men by drawing on her experience with brands such as Levi's and Axe/Lynx cosmetics).

The talk’s slide presentation links "comunicación y participación”, where, as Suso explains, the emotional effect on the participant-viewer is the key to its impact (rather, that is, than a brute commercial message being key). A stylized thought map schematically links "arte" with "brands" and "creación audiovisual" with "red". The latter is the telling combination that is at the heart of a publicity piece for the Spanish government's plan for high-speed broadband roll-out in Spain, whose narrative and visualization link creativity and audiovisual competency, on the one hand, with 330 million euros of co-funding on the other (Volando Vengo, "RED.ES").

The work has a strong thread of social commitment and participation - most obviously in a series of pieces for Entreculturas, a Jesuit NGO that addresses education and development. The most recent of these presents a partnership between Entreculturas and Accenture and has an upbeat focus on training in Andean communities for access to the labour market (Volando Vengo, "Videocase Entreculturas Accenture"). Underlying this kind of work is the less public layer of artistic and political action within Suso's Tumblr pages. There is a video diary of the Madrid Manifestación 19J2011 (part of the series of national marches against the Eurozone Pact, political corruption, lack of accountability and austerity measures imposed by the Partido Popular) (“Manifestación 19J2011”), and the feminist poem "El no camino", with accompanying video piece, denounces the ways in which "Las mujeres no tienen pasado / ni camino / nunca lo han tenido". Since 2012, however, the work has become increasingly geared to corporations and state institutions and engages with contemporary business and development interests. It explores the relationship between affectivity and effective working (and marketing), and it finds opportunity in "structural changes" in a "period of uncertainty" (as one draft piece for the civil engineering 
enterprise Cintra-Peajes Portugal euphemistically has it: "Cintra corporativo"). This strand of activity often has to overlook the expectations and values of the more socially committed work that runs in parallel. The property firm Tecnocasa is represented by a chirpy, upbeat piece on (mainly male) team spirit, where seizing the day, ambition and business growth offer a way forward and out of trouble, at a time (2012) when the ambitions of property developers were very obviously one of the causes of the recession (Volando Vengo, "La otra cara de la crisis"). A spot for Avon finds itself conveying the notion that Avon products will help women be the women they want to be (Multiplataform Content), at a time when in Spain as elsewhere women were being disproportionately disempowered by the effects of austerity (United Nations).

At other times, technical and stylistic affinities in Volando Vengo's commercial work create strong links between the values and images of the corporate and the social. Another of the series of pieces for Tecnocasa (Volando Vengo, "Somos uno") uses a rapid montage of faces and deft choreography of bodies to underline ideas of solidarity and concern. This echoes Volando Vengo's earlier work for the HIV/AIDS and sexual health and welfare campaign, VIVHO (Volando Vengo, "La vida no retrocede"). In spots for Absolut Vodka, J\&B, Agatha Ruiz de la Prada perfumes and Carrera and Carrera luxury goods (all on the Volando Vengo Vimeo pages), a fluid and sensual take on women's bodies harks back to earlier work and to the feel of the short Ester; its look also links it to the Volando Vengo-produced video-clip of 2015, "Hipersexualidad" (directed by Alberto Pareja), which visually engages with crucial debates about women's rights over their bodies and desires.

It is clear that Volando Vengo, in its work for a mix of clients, is involved in the shift away from the "dominant, technocratic view of CSR communication focused on goal attainment and based on a functionalist, transmission model of communication" towards "more dialogic and democratic framings" and an openness to "conceptions of communication that emphasize polyvocality and contested meaning" (Crane and Glozer 1246). This is grounded creative work that wants to change citizens' understandings of their ethical and ecological obligations as agents of 
change, as well as work that lends itself to making and remaking corporate and governmental images.

Rut Suso uses the "moviethinking" hashtag to label her own personal Tumblr page as well as the other Volando Vengo pages. This reinforces the bridge between the practicalities of transmedia storytelling and the protean energies of creativity, between the world of CSR and individual artistic integrity. On both the Tumblr and the Vimeo page for Rut Suso \#moviethinking, the About Me text reads:

Rut Suso, artista española camaleónica, rebelde y descentrada por elección propia. Esta versátil y escurridiza creadora se aventura con variados tipos de expresiones artísticas, aunque realmente se gana la vida con proyectos más formales. (Suso, Sobre mí)

The adjectives chosen here apply neatly both to traditional artistic and new entrepreneurial qualities and point to a hybrid auteurship and an inspirational making-do. The thus decentred Rut Suso works across several spheres of action as does Volando Vengo/Moviemaking as it continues to adapt.

\section{Conclusion}

This essay has woven together ideas of disruption, adaptation to new economic and artistic contexts and alternative modes of entrepreneurial creativity; it has connected these to some of the discourses and effects of crisis, precarity and austerity in one segment of the ongoing, and long-established, Spanish context of responses to neoliberal dispensation.

Carrillo's work is marked by the image of the queer, vulnerable body (and the vulnerable heart), by narrative and historical disruption and by generic instability. In particular, the body as a focus of crises of feeling and exclusion is a key component of his art as well as of his more functional image making for publicity. In the image work of Volando Vengo, increasingly redirected 
away from fictional filmmaking and placing commercial and social commitments in tensive relationship with artistic demands, the bricolage includes remnants of a feminist, corporeal and alternative lesbian image making but is made up mostly of corporate images and the discourses of social innovation. The crossovers between art making, filmmaking and commissioned makeovers in the work of both these case studies add further, textured detail to the cultural map of the Spanish crisis in process. Their artistic and pragmatic approaches also, of course, participate creatively in the general, global processes of digital disruption with its concomitant gifts of easier dissemination, targetting and sharing (Iordanova 6-8, 21-23) (gifts that are among the paradoxical products of neoliberalism). The strategies, images, moods and innovations focused on here arise from crisis and post-crisis - artistic, personal, social, commercial - and from the need to negotiate, articulate and finally disrupt them.

\section{Biographical note}

Chris Perriam is a Professor of Hispanic Studies at the University of Manchester (UK) and the author, recently, of Spanish Queer Cinema (2013) and coauthor of French and Spanish Queer Film: Audiences, Communities and Cultural Exchange (2016), both with Edinburgh University Press. christopher.perriam@manchester.ac.uk

\section{References}

Allbritton, Dean. "Prime Risks: The Politics of Pain and Suffering in Spanish Crisis Cinema". Journal of Spanish Cultural Studies 15.1-2 (2014): 101-15. Web.

Altabás Fernández, Ciro. "Autofinanciación y crowdfunding: Nuevas vías de producción, distribución y exhibición del cine español independiente tras la crisis financiera española". Historia y Comunicación Social 19 (2014): 387-99. Web. 
Álvarez Monzoncillo, José María, and Javier López Villanueva. “El audiovisual español: Evolución en curso". Informe sobre el Estado de la Cultura en España: La salida digital. Fundación Alternativas. Eds. Enrique Bustamante and Fernando Rueda. Report for Observatorio Cultura y Comunicación, Fundación Alternativas. Madrid: Fundación Alternativas, 2014. $65-74$.

Ashby, Arved. Introduction. Popular Music and the New Auteur Visionary Filmmakers after MTV. Ed. Ashby. Oxford: Oxford UP, 2013. 1-28.

Badillo, Ángel. "España: La producción audiovisual en el contexto de la crisis económica”. Comentarios Elcano. Instituto Elcano. 14 October 2013. Web.

Ballesteros, Gonzalo. "El cine español frente a la crisis”. Magnolia 28 (January-February 2012). Web.

La Bien Querida. Interview by JNSP. "La Bien Querida habla de la filosofía de vida de 'Poderes extraños"'. jenesaispop (2 October 2014). Web.

Bologna, Sergio, and Andrea Fumagalli, eds. Il lavoro autonomo di seconda generazione. Milan: Feltrinelli, 1997.

Bramall, Rebecca. "Introduction: The Future of Austerity". New Formations 87 (2016): 1-10. Web. Bustamente Ramírez, Enrique. España: La cultura en tiempos de crisis. Fuentes financieras y políticas públicas. Working document 12/2013 for Observatorio Cultura y Comunicación. Madrid: Fundación Alternativas, 2013. Web.

Cameron, Bryan. "Spain in Crisis: 15-M and the Culture of Indignation". Journal of Spanish Cultural Studies, 15.1-2: 1-11. Web.

Carrillo, Juanma. Personal interview. 19 March 2015.

---. “Juanma Carrillo: 'El peligro está ahí como un precipicio, pero al final el amor puede sobre todo"”. Música Crónica (9 July 2015). Web.

---. Hielo quema. Web. Accessed 30 March 2016. <hieloquema.com>. 
---. Une sensation de vide. Video art. Personal Works page. juanmacarrillo.com. Web. Accessed 30 March 2016.

---. Fuente Ovejuna promotional materials. Producciones anteriores page. \#LAJOVENCOMPAÑÍA. Web. Accessed 5 May 2017.

---. Hey Boy Hey Girl promotional materials. Commercials page. juanmacarrillo.com. Web. Accessed 15 May 2016.

---. Music Videos page. juanmacarrillo.com. Web. Accessed 15 May 2016.

---. Home page. juanmacarrillo.com. Web. Accessed 15 May 2016.

---. Proyecto Homero promotional materials. Commercials page. juanmacarrillo.com. Web. Accessed 15 May 2016.

Casal Lambda and Juanma Carrillo. “'Estafa', tercer teaser promocional Mostra FIRE!! 2012”, YouTube, uploaded by firemostra, 30 June 2012. Web.

Castells, Manuel, João Caraça, and Gustavo Cardoso. "The Cultures of the Economic Crisis: An Introduction". Aftermath: The Cultures of the Economic Crisis. Eds. Castells, Caraça, and Cardoso. Oxford: Oxford UP, 2012. 1-14.

Colectivo Precarias a la Deriva. A la deriva por los circuitos de la precariedad femenina. Madrid: Traficantes de sueños, 2004.

Coleman, Rebecca. "Austerity Futures: Debt, Temporality and (Hopeful) Pessimism as an Austerity Mood". New Formations 87 (2016): 83-101. Web.

Costa Sánchez, Carmen, and Teresa Piñeiro Ortiz. Estrategias de comunicación multimedia. Barcelona: Editorial UOC, 2013.

Crane, Andrew, and Sarah Glozer. "Researching Corporate Social Responsibility Communication: Themes, Opportunities and Challenges”. Journal of Management Studies 53.7 (2016): 1223-52. Web.

Cuenca, Julio A. “Poderes extraños': La Bien Querida”. Zona de Obras (5 October 2014). Web. De Bruin, Anne, Eleanor Shaw, and Dominic Chalmers. "Social Entrepreneurship: Looking Back, Moving Ahead". Handbook of Research on Small Business and Entrepreneurship. Eds. 
Elizabeth Chell and Mine Karataş-Özkan. Cheltenham: Edward Elgar Publishing, 2014. 392-416.

Di Domenico, MariaLaura, Helen Haugh, and Paul Tracey. "Social Bricolage: Theorizing Social Value Creation in Social Enterprises". Entrepreneurship Theory and Practice 34.4 (2010): 681-703. Web.

Dishonoured Bodies, compilation. Dir. Juanma Carrillo. TLA Releasing, 2015. DVD.

Duggan, Lisa. The Twilight of Equality: Neoliberalism, Cultural Politics and the Attack on Democracy. Boston: Beacon Press, 2003.

Elefant Records. Press note to release of "Premeditación", "Nocturnidad" and "Alevosía" by La Bien Querida. elefant.com, 15 April 2016. Web. Accessed 20 May 2016.

En construcción. Dir. José Luis Guerín. Wanda Visión, 2011. Film.

Ezpeleta, Joako. Personal interview. 19 March 2015.

Gill, Rosalind and Andy Pratt. "Precarity and Cultural Work In the Social Factory? Immaterial Labour, Precariousness and Cultural Work". Theory, Culture \& Society 25.7-8 (2008): 1-30.

Guillén, Ana M., Sergio González-Begega, and David Luque Balbona. “Austeridad y ajustes sociales en el Sur de Europa: La fragmentación del modelo de bienestar mediterráneo". Revista Española de Sociología 25 (2016): 261-72. Web.

Harvey, David. A Brief History of Neoliberalism. Oxford: Oxford UP, 2005.

Inside Job. Dir. Charles Ferguson. Sony Pictures Classics, 2010. Film.

Iordanova, Dina. “Digital Disruption, Technological Innovation”. Digital Disruption: Cinema Moves On-Line. Eds. Dina lordanova and Stuart Cunningham. St Andrews: St Andrews Film Studies, 2012. 1-31.

Kinkle, Jeff, and Alberto Toscano. "Filming the Crisis: A Survey". Film Quarterly 65.1 (2011): 39-51. Kourelou, Olga, Mariana Liz, and Belén Vidal. "Crisis and Creativity: The New Cinemas of Portugal, Greece and Spain”. New Cinemas 12 (2017): 133-51. Web. 
LesGaiCineMad. “¿El LesGaiCineMad peligra?”. Lánzanos crowdfunding project pages. 9 September 2014. Web.

Les Revenants. Dir. Fabrice Gobert. Canal+, 2012-2015. Television.

Mair, Johanna and Ignasi Marti. "Social Entrepreneurship Research: A Source of Explanation, Prediction, and Delight”. Journal of World Business 41.1 (2006): 36-44. Web.

Marsh, Steven. "¡No nos representan! Performatividad como cine militante, el archivo del 15-M”. laFuga 17 (2015). Web.

Martínez Gallardo, Francisco, and Jordi Alberich Pascual. "Plataformas y proyectos de Crowdsourcing y crowdfunding cinematográfico en España (2007-2011)”. Historia y Comunicación Social 18 (2013): 85-95. Web.

Multiplataform Content Agency. "Spot Avon”. Dir. Rut Suso. Vimeo, uploaded by Volando Vengo, 21 January 2015. Web.

Neilson, Brett, and Ned Rossiter. "From Precarity to Precariousness and Back Again: Labour, Life and Unstable Networks". The Fibreculture Journal 5 (2005). Web.

Oktyabr. Dir. Sergei M. Eisenstein. Sovkino, 1928. Film.

Perriam, Chris. Spanish Queer Cinema. Edinburgh: Edinburgh UP, 2013.

Perriam, Chris, and Darren Waldron. French and Spanish Queer Film: Audiences, Communities and Cultural Exchange. Edinburgh: Edinburgh UP, 2016.

Perrini, Francesco, Clodia Vurro, and Laura A. Constanzo. "A Process-Based View of Social Entrepreneurship: From Opportunity Identification to Scaling-Up Social Change in the Case of San Patrignano". Entrepreneurship \& Regional Development 22.6 (2010): 515-34. Web.

¿Quién puede matar a un niño?. Dir. Narciso Ibáñez Serrador. Penta Films, 1976). Film.

Rodríguez Ferrándiz, Raúl. “El relato por otros medios: ¿Un giro transmediático?”. Cuadernos de Información y Comunicación 19 (2014): 19-37. Web.

Rose, Nikolas. Powers of Freedom: Reframing Political Thought. Cambridge: Cambridge UP, 1999. Scolari, Carlos Alberto, Manel Jiménez, and Mar Guerrero. "Narrativas transmediáticas en España: Cuatro ficciones en busca de un destino cross-media". Comunicación y Sociedad 25.1 (2012): 137-63. Web. 
Shaw, Eleanor, and Sara Carter. "Social Entrepreneurship: Theoretical Antecedents and Empirical Analysis of Entrepreneurial Processes and Outcomes". Journal of Small Business and Enterprise Development 14.3 (2007): 418-34. Web.

Suso, Rut. "Manifestación 19J2011 Madrid". Vimeo, uploaded by Rut Suso \#moviethinking, 14 June 2012. Web.

---. “Conferencia moviethinking”. Vimeo, uploaded by Volando Vengo, 16 December 2012. Web.

---. “El no camino". Text and video-poem. Prosa poética page. Moviethinking. Tumblr blog. 30 March 2013. Web.

---. Home page. Moviethinking. Tumblr blog. 30 March 2013. Web.

---. Sobre mí page. Moviethinking. Tumblr blog. Accessed 15 May 2016.

United Nations. Committee on the Elimination of Discrimination against Women. Concluding Observations on the Combined Seventh and Eighth Periodic Reports of Spain. 29 July 2015. Web.

Vernalis, Carol. Unruly Media: YouTube, Music Video, and the New Digital Cinema. New York: Oxford UP, 2013.

Volando Vengo. About page. volando vengo movie thinking Vimeo page. 3 December 2008. Web. ---. “La vida no retrocede”. Spot for Fundación Triángulo VIHVO campaign. Vimeo, uploaded by Volando Vengo, 9 February 2011. Web.

---. "Cintra corporativo". Draft corporate video for Cintra (Ferrovial group). Vimeo, uploaded by Volando Vengo, 8 March 2011. Web.

---. "Somos uno". Video reportage of Tecnocasa annual convention. Vimeo, uploaded by Volando Vengo, 17 November 2011. Web.

---. "La otra cara de la crisis". Promotional video for Tecnocasa. Vimeo, uploaded by Volando Vengo, 18 December 2012. Web.

---. "RED.ES Plan Nacional de Conectividad". Government information video. Vimeo, uploaded by Volando Vengo, 27 March 2015. Web. 
---. "Videocase Entreculturas Accenture". Presentational video. Vimeo, uploaded by Volando Vengo, 7 April 2015. Web.

WeShoot Agency. "Fraud/Estafa". Video on demand. Vimeo, uploaded by Emociones Produce, 20

October 2015. Web.

Zurro, Javier. "El ICAA recorta un $62 \%$ en la protección del patrimonio del cine español”. El Confidencial (20 September 2003). Web.

\section{Notes}

i Other responses to the low- or no-budget circumstances of the period, including self-financed and crowdfunded projects, are studied by Martínez Gallardo and Alberich Pascual and, more briefly, by Altabás Fernández, who has a useful bibliography of Spanish web-based studies of the topic.

${ }^{2}$ The agency spells its name in various ways, perhaps to avoid clashing with the Seattle-based agency of similar name.

${ }^{3}$ For the final edit, see WeShoot Agency. 